\title{
HISTORY CURRICULUM POLICY OF SENIOR HIGH SCHOOL DURING SUKARNO ERA
}

\author{
Zulkarnain \\ Department of History, Faculty of Social Sciences, Universitas Negeri Yogyakarta
}

\begin{abstract}
This article aims to investigate the history curriculum policy of senior high school during the Sukarno era. The method used is qualitative research by using the historical approach. Also, this research used document study as the primary method. A document study was conducted to both the primary and secondary sources for the source triangulation. Additionally, the complementary approach used interviews with several practitioners and academics, including the practitioners of the Indonesia history curriculum. Data analysis used an interactive analysis model. The results show that during 1945-1951, the history curriculum of senior high school still used AMS (Algemene Middelbare School) curriculum as the inheritance from the Dutch Indies era, so it is directed to the political policy, and the materials are clearly oriented to politics, doctrine, national ideology. The philosophical foundation of history curriculum policy in senior high school during the Sukarno Era is based on Pancasila and UUD 1945. But its implementation refers to government politics and essentialism and perennialism philosophy. The position of history subject in senior high school during the Sukarno era has a strategic role in creating historical awareness and nationalism. However, Manipol USDEK indoctrination was very visible.
\end{abstract}

Keywords: education policy, history curriculum, senior high school.

\begin{abstract}
ABSTRAK
Artikel ini bertujuan untuk menyelidiki kebijakan kurikulum sejarah SMA pada era Sukarno. Metode yang digunakan adalah penelitian kualitatif dengan menggunakan pendekatan sejarah. Selain itu, penelitian ini menggunakan studi dokumen sebagai metode utama. Studi dokumen dilakukan pada sumber primer dan sekunder untuk triangulasi sumber. Selain itu, pendekatan komplementer menggunakan wawancara dengan beberapa praktisi dan akademisi, termasuk praktisi kurikulum sejarah Indonesia. Analisis data menggunakan model analisis interaktif. Hasil penelitian menunjukkan bahwa selama tahun 1945-1951, kurikulum sejarah sekolah menengah atas masih menggunakan kurikulum AMS (Algemene Middelbare School) sebagai warisan dari jaman Hindia Belanda, sehingga mengarah pada kebijakan politik, dan materi yang jelas berorientasi pada politik, doktrin, ideologi nasional. Landasan filosofis kebijakan kurikulum sejarah di Sekolah Menengah Atas pada masa Sukarno berpijak pada Pancasila dan UUD 1945. Namun implementasinya mengacu pada filosofi politik pemerintahan dan esensialisme dan perenialisme. Kedudukan mata pelajaran sejarah di sekolah menengah atas pada era Soekarno memiliki peran strategis dalam menciptakan kesadaran sejarah dan nasionalisme. Namun, indoktrinasi Manipol USDEK sangat terlihat.
\end{abstract}

Kata kunci: kebijakan Pendidikan, kurikulum sejarah, Sekolah Menengah Atas. 


\section{INTRODUCTION}

The curriculum of Indonesia's history subject has a strategic meaning in creating dignified characters and nation civilization and in creating Indonesians who have nationalism and patriotism. It is because history learning has general roles including developing the understanding of oneself; providing the precise illustration related to the concept of space, time and people; making people evaluate values and results achieved by their generation; teaching tolerance; instilling intellectual attitudes; expanding intellectuals; teaching moral principles; instilling orientation to the future; providing mental training; training students to deal with the controversial issues; assisting solutions for several social and individual problems; strengthening nationalism; developing international understanding; and developing useful skills (Kochar, 2008, pp. 27-37)

Widja (1989, p. 38) explained that the Indonesia history curriculum actualized in materials or the content of history subjects becomes an important aspect that should be paid attention by the history teachers. The elements of the history theme emphasize time, space, and place issues. Related to time constrain, history can be divided into "general history' and "contemporary history." General history emphasizes the content about the illustration of human evolution from early life to the present day, so there is no strict time constrain. However, contemporary history emphasizes more on materials related to the illustration of event development. Emphasis on space or place allows them to distinguish history into the one whose materials are limited, and the other one has a broader scope.

The main problem which restrains the Indonesia history curriculum is the politicization of history education is the change of education sector together with changes in leadership in Indonesia. It has an impact on successful student learning in Indonesia's history subject. In outline, two variables that can influence the success of student learning are the availability, and support of inputs; and learning quality. Input consists of students, teachers, curriculum, and learning facilities. The learning quality is the standard in showing how high the quality of interaction between teacher and student in the learning process to achieve particular purposes. The learning process is carried out in a specific situation supported by curriculum and learning variables. Hence, the success of the learning process depends on the teacher, student, curriculum, learning facilities, class environment, and class culture. All indicators have to support one another in a quality learning activity system.

From a historical view, the education curriculum in Indonesia was firstly born in the independence era using the term leer plan, which means planning or lesson plans. The content of the curriculum gave superiority in education in creating characters and the nation and social awareness. Besides, the materials were also related to daily events, attention to the arts, and physical education. Leer plan was used in 1950, which contained the lists of subjects and teaching hours as well as a teaching outline. The 1952 curriculum was called a decomposed lesson plan, which was more detailed for each item by specifying the syllabus for each subject. In 1964, there was a change of curriculum called Rentjana Pendidikan 1964. The contents of this curriculum are that learning was centered in the Pantjawardhana program (Hamalik, 2004, p. 27), which was moral development, intelligence, emotional/artistic, crafty, and physical aspects. The birth of 1968 Curriculum was political, which was as the substitution of the Rentjana Pendidikan (Education Plan) 1964 because it was imaged as an Sukarno Era product. The purpose was related to creating a true Pancasila man. The 1968 Curriculum emphasized the organizational approach of subject materials: Pancasila formation group, basic knowledge, and special skills. The number of subjects was nine.

After Presidential Decree on 5 July 1959, the history curriculum was more referred to as history as a tool to convince 
President Soekarno's ideas. Then, in 1964, curriculum policy was very political. The new style of this was used as a platform for the legitimacy of governmental policy authorities, which caused partial justification towards the applied leadership theory. At that time, education had to be based on Pancasila and Manipol (Political Manifesto of UUD 1945, which consisted of Indonesia Socialism, Guided Democracy, Guided Economy, and Indonesian Personality). If the doctrine were applied based on the fundamental theory, the policy would be accepted with common sense, including the concept of "Guided Education."

Studying the history of the curriculum is a fascinating subject. Previous studies have, therefore, been conducted. In general, Belen (2010) looked at the history of the curriculum in Indonesia. Syukur (2013) examines the history curricula of the era 1964-2004. There is also a study in Batubara (2019) on learning history from post-independence to reform.

Nevertheless, studies on the history of the curriculum are still under general review. They didn't focus on how the history curriculum was in Sukarno's time. In the meantime, during the Sukarno period, Umasih (2014) researched the policies of the Sukarno Era in the field of education, especially in elementary schools. Research is also being carried out by Fadli \& $\mathrm{Ku}-$ malasari (2019) on the Indonesian education system during the Sukarno Era. However, the study of the curriculum during the Sukarno era did not focus on the study of historical subjects. This study, therefore, focuses on the development of a history curriculum in high schools in the Sukarno period. At the same time, this research intends to fill the gaps in previous studies.

\section{RESEARCH METHODS}

The research used is qualitative research by using a historical approach. The historical method includes several stages in critical way namely: (1) selection of research topic, (2) heuristics, (3) internal and external critics, (4) interpretation, and
(5) the final stage is historiography by writing history into a real and exciting story (Kuntowijoyo, 2013, p. 91). This research using document study as the primary method. The primary sources used in this research are Dokumen Indonesia No. 2, Instruksi Menteri Pendidikan Dasar dan Kebudayaan No. 2 Tahun 1961, Kepres No.145 $28 \mathrm{Mei}$ 1965, Pewarta PPK No 2/1951, and Undang-Undang No. 4 Tahun 1950 tentang Dasar-Dasar Pendidikan dan Pengadjaran di Sekolah Act of Republic Indonesia number 4, the year 1950 about Fundament of Teaching at Schools). Besides, document study to both primary and secondary sources for triangulation sources. Additionally, this research also used interviews as a complementary method (Miles \& Huberman, 1994, p. 16).

\section{RESULTS AND DISCUSSION}

\section{The Dynamic of Education Policy}

Research of education policy, including the study related to the history curriculum, can be classified into the research field of public policy. The classification of policy research was based on several arguments and academic considerations. Hence, the curriculum always becomes a foothold by the government as a policymaker to determine education in a country. The results of the analysis study related to curriculum policy have positive impacts on the nation as well as other aspects such as quality assurance, education administrators, and the issues related to overall education funding. This explanation is similar to what Richard Elmore's said (Elmore \& Sykes, 1992, p. 188), the policy research requires a well-organized study, so curriculum study and the politic policy in a country are not only in the form of action, but they are also oriented in events and simplification to answer the problem concerning good and ideal curriculum.

Researcher agree with Richard Elmore's theory, so it is reasonable to be used as one of the supporting theory of the research to improve research data. Education policy including research related to curriculum policy of history subject at senior high school issued by the state official 
instrument Kepres (President Decrees), Inpres (President Instruction) or other strategies such as Decrees of Ministry of Education, is the results of dialogues and public testing from academic documents which refer to an agreement between two state institution, namely executive and legislative institutions. These statements indicate that public policy related to the study of education and curriculum can not be separated from power, so the system will directly imply the society in the present and the future.

Curriculum policies as actions and collective agreements in the field of education are related to society. If the policies issued by political institutions, namely executive and legislative institutions, which one of them are curriculum education whether it is general or history subject from one period to other periods, always cause conflicts between groups, pros, and cons. Therefore, to avoid these conflicts, wisdom is necessary from various parties, which is known as wisdom politics or, in other words, "a policy requires wisdom" (Ricklefs, 2008, pp. 40-41).

In public policy, we often hear the term that a nation and its society are the results of the realization process of aspiration and struggles of community groups with any obstacles and challenges. Hence, it is appropriate if the historical education curriculum can be applied in a formal education process that can be used as media in a proper and effective political education and can be developed as a positive thinking foundation about the nation's presence. History learning also can be media that reflect the dynamics of political life and other aspects of life, so it can be used as a reflection for developing a nation's presence in the present and the future. Education as a conscious effort in creating a person who is spiritually, social$1 y$, emotionally intelligent so that they will be a more dignified agent of change for the nation. The politics in a country are dominant in changing the education curriculum, including the history curriculum, in which all consequences are better.
Curriculum changes as a representation of policy are compromise political actions between executive represented by the government (Ministry of National Education) and the legislative institution as a representative from people through a democratic election, so this is a solution between competing interests. In line with the argument above, Taylor et al. (1997, p. 13) argued that curriculum policy is dynamic and interactive, and it is not only a set of orders or intentions. The system of education curriculum is a political compromise between contradicting images about how changes should work. The political agreement can be achieved through the process of negotiation values by the government to the influential groups in society. It is in line with Easton's opinion and thought, he argued that policy is decision and action networks which determine values, the truth of policy (Easton, 1953, p. 30)

The linkages between curriculum policy and politics clearly can be seen, especially in the history curriculum in senior high school, and the political foundation and the policymaking process and the development in changing curriculum seem very clear. Thus, the political foundation of history education becomes the primary consideration. It because the materials are oriented more in where and how the state and nation are formed. Also, how the struggles have been carried out by the national heroes and how to maintain and to do positive actions after independence. Based on these considerations, history education is political media to build collective memory as a nation (Easton, 1953, p. 33)

The history department cannot only discuss in one period to other periods, but the discussion also has to chronological. It is caused by interrelated periods or in simple words. It can be explained studies of the Indonesia history curriculum should be coherent, systematic, and sequential among one event to others, between one period to others, so the red thread and the interconnectedness between policy and other policies in different periods can be seen. 
According to the findings and data analysis can be explained that in 19451951, Senior High School used curriculum as a result of the Dutch East Indies curriculum. The impacts using the curriculum were that history learning was more European-centric, and it also kept students away from the principles of nationhood. Hence, the national history taught was the history of great people and Dutch reigns in Indonesia. History learning does not show the role of the history of people who helped to achieve Indonesia's independence. However, it does not mean that history should be Indonesia-centric, which ignores the objectivity of history study, so it sticks to the principles of historical objectivity. The problem of relations between Indonesia is centric and historical objectivity that continues to be discussed in each national historical seminar from time to time (Hakim, 2018, pp. 72-78)

In 1952, the history curriculum changed into a science-based curriculum because it paid less attention to students' skills, and it was judged too academic, so this curriculum did not last long. Then in 1964, the history curriculum was very close to political nuances, so the history curriculum became increasingly rigid. The "guided-style" curriculum was used as a platform for the legitimacy of the ruler's political policy, which resulted in unilateral justifications towards the applied leadership theory. Hence, the history curriculum could not achieve its actual goals.

\section{The Policy of History Curriculum at SHS during the Sukarno Era}

The change and renewal of the education curriculum in Indonesia could not be separated from the government's intervention and politicization by the dominant political party. The curriculum policy from one period to other periods occurred alternately when the paradigm of the power always changed based on its subjective terminology. If we looked carefully during 19451951, Senior High School used the AMS curriculum (Algemene Middelbare School), which was the Dutch East Indies' inheritance. It could be understood because
Indonesia declares its independence, so human resources and other complementary sources were limited. In early of the Sukarno era education always became a notable thing for the rulers since it was used as a tool and a medium to support the development concept and strategy, and political intervention to the education policy might have both positive and negative impacts (A.W. Adam, personal communication, July 2016; Adam, 2005).

Defacto, on 17 August 1945, Indonesia became an independent nation and was free from colonialism and colonizers. Thus, the initial step to support them, which was officially published in the Indonesia Constitution and Preamble of the 1945 Institution, was to educate the nation's life through education. The day after Indonesian independence, Indonesia issued the Constitution, namely the 1945 Constitution. Furthermore, national principles and philosophy were released, namely Pancasila and then became fundamental in running national education system (UUD 1945)

Education in Indonesian after independence changed and improved. The education system which was initially oriented to the colonialists' interest or colonialcentric, European-centric. After Indonesia became an independent country or known as post-independence, the orientation of education started to change, both in philosophy and the purpose of education. The use of education after independence was clearly and firmly to educate the nation's life and oriented to build people's nationalism to their country. It was in line with the preamble of the 1945 Constitution (fourth paragraph). The 1945 Constitution mentioned that one of the national development ideals was to educate people. During the Sukarno Era, the government focused on improving education as an effort to build national character. In this era, every person was equal without discriminating against each other from many aspects. Moreover, the Sukarno Era was trying to create secure civilians that stood on democracy, equal rights, and obligations among fellow citizens, including in 
the education aspect.

As an independent and sovereign country, so for precisely two days on 18 19 August 1945, PPKI held an official state trail or known as the first state trial. The trials agreed and unified the decision, namely establishing institutions and departments to run the government. The agreements succeeded in establishing twelve departments; one of them was PPK. Moreover, another decision was on 19 August 1945; PPKI also found KNIP and KNID as the Indonesian Parliament, Police of Republic of Indonesia, and National Army. The committee was led by Abdul Kadir and his members Otto Iskandar Dinata and Kasman Singodimedjo (Pusponegoro \& Notosusanto, 2008, p. 97).

From the PPKI trial, PPK Department was given full authority to compile the education system and its implementation, including curriculum drafting. The position of Ministry of PPK was entrusted to Ki Hadjar Dewantara, the consideration of assigning him as the ministry of education because of his personal experience to educate people through his education system known as Taman Siswa.

The pattern of education development by Ki Hadjar Dewantara attracted President Sukarno, so he was finally entrusted with improving education in Indonesia through cultural approach and local wisdom. Before the Constitution was issued, the effort to change the colonial to national education had been implemented. The first education ministry, $\mathrm{Ki}$ Hadjar Dewantara, issued the General Instruction to the teachers to improve the colonial teaching system into teaching to build national spirit. It occurred less than a year after Indonesian independence.

Ki Khadjar Dewantara was an educational figure who succeeded in establishing policy, which then became fundamental or the basis of the national education system based on culture, patriotism, and nationalism (Tilaar, 1995, p. 70). Under the reign of the Ministry of Education, $\mathrm{Ki}$ Hajar Dewantara, education was developed using the "among" knowledge based on the principles of independence, nature, culture, and humanity. It is known as "Panca Dharma Taman Siswa" and the motto "ing ngarso sung tuladha, ing madyo mangun karso, tut wuri handayani". In 1950, the National Education Regulation was firstly issued that was related to the principles of education and teaching at school (Act of Republic Indonesia number 4, the year 1950).

The purpose of national education during the early independence was based on the process of building patriotism spirit and increasing national awareness so that the independent spirit would be maintained. The Minister of Education, Teaching, and Culture of Indonesia in 1946 issued a guideline for teachers. The guidance contained the characteristics of humanity and citizenship. It becomes the basis of teaching and education in Indonesia, which was based on Pancasila.

However, due to the unstable political condition, his position as the Minister of PPK lasted in a short time, which was in four months from 14 August to 14 November 1945. Ki Khadjar Dewantara finally was then replaced by Mr. T. S. G. Mulia, from 4 November 1945 to 27 June 1946. After the inauguration on 29 December 1945, Central Indonesia National Committee for Workers Institution proposed the Ministry of Education and Culture to immediately establish foundation and renewal of education and teaching (BPKNIP Meeting on 27 December 1945). The redevelopment included: First, to develop a new society, learning guidelines were required. Individual understanding should be changed into the knowledge of decency and high humanity. Education and teaching had to educate students to be citizens who had a sense of responsibility. Second, to strengthen unity, one type of school for all levels of society had to be established. Remember, based on the principle of social justice, all schools had to be open for all people, both men, and women.

Third, methods applied at schools should be based on the work school system, so the people's activities at work 
would develop widely. Besides the general schools, schools for adults which provided literacy lessons and so on should be established. For instance, Taman Ilmu Rakyat by considering the highlights of item 1 above. Moreover, schools of community leaders for each critical business field were necessary. The headquarter should be built for these schools. Fourth, religious teaching should have a proper place and got more attention by gave freedom to the groups for following their beliefs. For the implementation, the Minister had to discuss with BP-KNIP. Fifth, madrasah and Pesantren (Boarding School), which were one of the education media and sources in educating people from a long time ago, should get more attention and real assistance, either in guidance and money from the government. Sixth, universities should be implemented broadly and if it was necessary, using foreign teachers as a professor. Furthermore, student exchange was also needed. Seventh, an obligation to study should be carried out in a short time, a maximum of ten years, and every elementary student had an opportunity to learn for six years. Seventh, technical and economic learning, especially in agriculture, industry, shipping, and fisheries, should get special attention.

Teaching health and physical education should be implemented regularly to obtain harmonious people's intelligence (Pusponegoro \& Notosusanto, 2008, p. 86). Beside eight points above, the reforms by Minister and Education were called PPK Minister. This institution did not justify the elementary schools to collect money from the students. Still, for high schools and universities, tuition and allowance should be made, so financial matters did not become obstacles for needy students. Similar to $\mathrm{Ki}$ Khadjar Dewantara, Mr.T.S.G. Mulia, he reigned in a short time and then replaced it with Mr. Suwandi.

Mr. Suwandi served as the PPK Ministry from 2 October 1946 to 27 July 1947. During the reign of Suwandi as the PPK Ministry, the government succeeded in establishing the committee of Indone- sia's teaching investigator. The committee was exemplary in building the foundation of national education because the committee reached in to formulate the official national education system, and this system is similar to the education concept by $\mathrm{Ki}$ Hadjar Dewantara. (Pusponegoro \& Notosusanto, 2008, p. 87). Based on the writer, the same education concept cannot be separated from the position of Ki Hadjar Dewantara, who was appointed by Suwandi as the chairman of the education system formulator.

In 1947, the government was issued the Decree of the Ministry of Education, Teaching, and Culture signed by $\mathrm{Mr}$. Suwandi. The policy was related to the curriculum policy. This decision was an aspect of curriculum ideas and stated in the guidelines of primary teaching. The decree was published in Pewarta PPK Number 2 the Year 1951 which established the guidelines of primary education that had to consist of: (1) devotion to God, (2) love nature, (3) love to the state, (4) love and respect to parents, (5) love to nation and culture, (6) right and obligation to build a state based on their strength, (7) the belief if people are inseparable to family and society, (8) the idea that people should obey the rules, (9) the belief that all human are same, so they have to respect each other based on justice and cling firmly to their pride, and (10) the notion that state needs hard-working and honest (both mind and action) citizens (Pewarta PPK No. 2 Tahun 1951).

The foundation established by Mr.Soewardi in 1947, which the education curriculum was firstly emerged after Indonesia's independence by using the Dutch term called "leer plan" (learning plan). The Ministry of Education carried out one of the critical efforts to develop national education, Teaching, and Culture (Mr. Soewardi), namely by changing national education and teaching, so it was more in line with the nation's urges and ideals. The change was more political, from the Dutch education orientation to the national interest. The curriculum during that period was known as the "1947 
Lesson Plan", which was only implemented in 1950. The direction of the 1947 Lesson Plan was every lesson plan at every school level at that period by taking into account as follows: (1) reducing mind education, (2) linking the materials to the daily life, (3) paying attention to arts, (4) increasing physical education, (5) increasing character education, (6) increasing state and community awareness (Aman, 2015, p. 17).

The 1947 Lesson Plan, which had a simple arrangement, only contained two main elements that were the lists of teaching hours or program structure or the outlines of the teaching program. The 1947 Lesson Plan was divided into three program structures including (1) schools using local language (Javanese, Sundanese, and Maduranese) as a language instructor; (2) schools using Bahasa Indonesia as a language instructor, and (3) schools held on the evening due to the limited available class during that time. Hence, the teaching program structure in the 1947 Lesson Plan consisted of 16 subjects, and three of them namely local languages (Javanese, Sundanese, and Maduranese) based on the students' location, female work for girls and religious education based on their religion (Aman, 2015, p. 34).

The committee succeeded in drafting the national education laws in 1948. The Ministry Education approved this draft of education. Therefore, the selection, which had been discussed by $\mathrm{Ki}$ Hadjar Dewantara as the chairman of the education formulator committee, was again mentioned during the BP KNIP session, which had a function to substitute the House of Representatives. However, the draft of the law on the national education system encountered obstacles and failed to be legalized by BP KNIP. It was due to the Dutch attack on the capital city, Yogyakarta, precisely in 1948. As a result, the Dutch forces arrested Indonesia President and Vice and some ministries as well as confiscated all state documents, including a draft of the law on national education system (Pusponegoro \& Notosusanto, 2008).
Thoughts influenced the formulation of strategy and national education policy based on culture. Furthermore, the Ministry of PPK during the Muhamad Hatta II cabined was served by Ki Sarino Mangunkaskoro, who had a similar background as $\mathrm{Ki}$ Hadjar Dewantara, both came from Taman Siswa. They have the same concepts to develop education-based culture (4 August 1949 to 6 September 1950). The Ministry of PPK, Ki Mangunkaskoro, re-proposed the education concept based on culture. Thus, this concept was discussed again in the BPKNIP session from 26 to 28 October 1949. There was a heated debate during the session especially related to the purpose of education, the language of instruction, learning obligations, scholarships, and physical education.

Finally, BP-KNIP approved the purpose of national education, and the education draft bill was ratified into law by the government on 2 April 1950, into UndangUndang No. 4 Tahun 1950 (Act of Republic Indonesia number 4, the year 1950 about Fundament of Teaching at Schools). The ratification was carried out when NKRI became the union state. Due to the change of state system from NKRI to the United Republic of Indonesia, the Republic of Indonesia became a part of the United Republic of Indonesia under the leadership of Ir. Sukarno as the president and Muhamad Hatta as the vice president. Meanwhile, the president of the state of the Republic of Indonesia was held by Mr. Asaat Datuk Mudo, the former chairman of BP KNIP (Hakim, A. \& Giovani, 2012, p. 165).

Based on Act of Republic Indonesia number 4, the year 1950, the study of national education policy formalized as the Education Laws were firstly ratified by Mr. Asaat, on behalf the president of the state of Republic of Indonesia and were promulgated by the Minister of Justice of the state of Republic of Indonesia, A.G.Pringgodigdo. Meanwhile, there was an interesting fact related to the National Education Laws 1950. Even though the Laws were ratified by the president of the 
state of the Republic of Indonesia, the implementation was applied to all countries, including RIS (the Republic of the United States of Indonesia) (Document of National Education Laws 1950). The expansion of the laws' enactment was carried out after an agreement between the Prime Minister of the state of the Republic of Indonesia, dr. Abdul Halim, and the Prime Minister of the Republic of the United States of Indonesia, Drs. Mohamad Hatta. The national education policy was considered as a joint policy between the two countries. It could be stated that in 1950, the Republic of Indonesia issued the first Laws concerning education and then were used by RIS and later was reused by the Republic of Indonesia named Act of Republic Indonesia No. 12, the year 1954 (Hasan, 2010, p. 116).

There was an explanation about the Act of Republic Indonesia number 4, the year 1950 that the purpose of national education was to carry out national and democratic education. The state should develop a national education system for all regions of the Republic of the United States of Indonesia. The patterns of education implementation had to be different from the education system, which had been used by the Dutch government, which was colonialism and Europeancentric. They avoided education, which alienated people from their cultural roots (Act of Republic Indonesia number 4, the year 1950).

In Act of Republic Indonesia, number 4 , the year 1950 article numbers 8 and 9 explained that national education guaranteed "the necessity of our education towards national culture" (Act of Republic Indonesia number 4 , the year 1950). The government policy, after the issued Act of Republic Indonesia number 4, the year 1950 towards national education, had placed the Indonesia history curriculum to an honorable position. The state paid history teaching in special attention. History teaching was expected to reverse situation and condition, from the European-centric instruction and pro-colonialism, which caused people gradually eroded culture, which was a genetic legacy from the Dutch colonial government (Kartodirdjo, 2000, pp. 12-36).

Act of Republic Indonesia number 4 , the year 1950, was able to give a particular space for the history curriculum. The history curriculum was expected to be implemented in a quick learning process and built nationalism of the younger generation to the beloved nation, Indonesia. During the colonialism era, Indonesians felt alienated from their history because the educational institutions were more likely to discuss and to tell history from overseas countries. The history of colonial state and justification for steps and actions by the colonialists, so Indonesia history became a guest in its own country (Act of Republic Indonesia number 4, the year 1950).

After the policy of Act of Republic Indonesia number 4, the year 1950 was issued by the government, several curriculums for each level of education were shown during the Sukarno Era, namely curriculum for elementary school. The purpose of primary education was to prepare children to have basic knowledge, skills, and ability to develop their interests and talents. Secondary education aimed to prepare the students for higher education and educating the experts in various particular fields based on their skills and needs in society. Finally, the higher education referred to prepare the students to be a leader in society and to maintain the scientific and community progress at that time.

Sarmidi Mangun Sarkoro, who was the Ministry of PPK during that time, succeeded in build a foundation of history education marked by the emergence of Act of Republic Indonesia number 4, the year 1950 . Due to the unstable political system characterized by the ups and downs of the cabinet, in 1951, he was replaced by Bahder Djohan. The program by the new ministry of PPK was to establish National History Committee. National history was assumed as the only way to prevent division and political disintegration as a result of the heated politics approaching the democracy party (Aman, 
2015, p. 78).

Prijono chaired the National History Committee, and the members were historians from the University of Indonesia, and Dutch historians worked at the University of Indonesia and Athe Archeological Service. The establishment of this committee was motivated by the government's view that the Indonesia history subject could be used as strategic media in building the character and personality of the citizens through history teaching. Hence, the only way was to revise the materials in Indonesian history, teaching books, and practical and essential textbooks (Soedjatmoko et al., 1995, p. xiii). However, this team failed to compile history textbooks and materials due to the unstable political condition and situation marked by the ups and downs of the cabinet as a result of a no-confidence vote from parliament and the limited time as well as insufficient sources as references in writing Indonesia history (A.W. Adam, personal communication, April 2016)

Even though the compilation of history textbooks failed, the importance and strategic position of history teaching in the education system did not change. The location of history teaching was more durable after Muhamad Yamin was appointed as the Ministry of PPK, who replaced Bahder Johan. The first program by $\mathrm{Mu}-$ hamad Yamin was the resubmitted Act of Republic Indonesia number 4, the year 1950 to the house of Representatives. This submission was necessary because this law was ratified when the state was federal, while since August 1950, Indonesia returned to a unitary state. On 27 January 1954, the heads of House of Representatives approved the reenactment of Act of Republic Indonesia number 4, the year 1950 , without any changes. Both in terms of the preamble and its articles related to education. This approval was ratified by President Sukarno on 12 March 1954 as Act of Republic Indonesia number 12, the year 1954 about the enactment of Act of Republic Indonesia number 4, the year 1950 from the former republic concerning the Basic Education and Teaching at school for entire Indonesia. The statute was promulgated by the Minister of Justice, Djody Gondo Koesumo, and the Minister of PPK Mr. Muhamad Yamin on 18 March 1954 (Act of Republic Indonesia number 12, the year 1954 about the enactment of Act of Republic Indonesia number 4, the year 1950).

During his reign as the Minister of PPK, Muhamad Yamin, education policy, was paid close attention to building nationalism through history teaching at schools. The failure of National History Committee in 1951 led by Prijono immensely influenced the government's effort to overcome the confusion of history teaching materials at schools which had occurred since 1945

The confusion of history learning materials was caused by several factors, such as The Ministry of PPK established a policy that was very beneficial to history learning because it became the priority subject at schools. The ministry of PPK gave space and instruction, so the history learning process at schools required supporting facilities, namely providing textbooks. This instruction was welcomed enthusiastically by the history practitioners, academicians, teachers, and history writers. Unfortunately, the enthusiasm for writing history textbooks was not standardized well, especially the history materials for public education and public school. Teachers in both schools tried to write the history dictates and then were published as a book. The enthusiasm which was not standardized had a fatal consequence. That was the quality of history textbooks inadequate. It could be seen in the part of overviews, summary, and Indonesia history main points. The large number and types of Indonesia history textbooks created chaos in history learning at schools and in the general public (D. Suryo, personal communication, August 2016).

A presidential decree on 5 July 1959 began the process of education politicization, especially Indonesia's history. The decree was known as the era of the indoctrination national education era by Sukarno to support the domestic and foreign 
political policy. The indoctrination materials were collected from several manuscripts of President Sukarno's speech on various occasions. To strengthen indoctrination, MPRS, which was a state institution as a result of the presidential decree on 5 July 1959, established MPRS decree, which mainly regulated national education. It was stated in Tap MPRS No II/ MPRS/1960, which said Pancasila and political manifesto as the obligatory subject from the elementary schools to universities and directed national education system to create experts in development following the requirements of Indonesia socialist society. Based on the TAP MPRS, President issued Presidential Decree, which used national education as a revolutionary tool against imperialism, colonialism/neocolonialism, feudalism, and capitalism. Hence, Presidential Decree was formulated revolutionary, which was Presidential Decree No. 145 on 28 May 1965. (Presidential Decree No.145 the year 1965).

The Minister of PPK was famous for being loyal to President Sukarno, namely Prijono. He executed policy and instruction from President Sukarno by giving full supports to the indoctrination policy in history education. Less than a month after Presidential Decree on 5 July 1959, instruction No. 1/17 August 1959 was issued. The content was to obligated all PPK Ministry officials to adapt to the political change after Presidential Decree 5 July 1959. Based on the instruction of PPK Minister, the Head of General Education Office, Ali Marsaban, established a particular agency, namely Sapta Usaha Tama Affairs (implemented at school level) and Pantjawardhana. Pantjawardhana concerned the new educational system, which was based on five developing principles, namely morals, intelligence, emotional-autistics, skills, and physic (Hartono, 2017, p. 38).

Pancawardhana concept was then used as a long-term flagship program by the Ministry of PPK in Sukarno Cabinet. To strengthen the implementation of the Pantjawardhana program, Prijono issued the second instruction on 17 August 1961, which was influenced by Presiden Sukarno's ideas in conducting indoctrination of national education. Based on this instruction, the new curriculum was compiled by the assistant of the Ministry of Education, Mr. Soepardo. Then, he assigned the Head of General Secondary Education Affairs, Idris M.T. Hutapea, for Senior High School subjects. The preparation of new high school was initially established in work meeting participated by the Directors of State and Private High Schools throughout Indonesia located in Bandung from 25 April to 2 May 1962. The first draft was then discussed again in a meeting of New Style Education Laws held from 21 to29 March 1963 in Tugu, Bogor Regency. This lesson plan was known as Pantjawardhana lesson plan (Instruksi Kementerian PPK, 17 Agustus 1961)

History subject in the first grade of high school was also included as a part of the particular topic. Meanwhile, history subject at the second grade was based on the majors, so history subject was not taught in science major, but social science and culture majors. The national history subject at junior high school supported the Civic Education subject as the main subject. This subject aimed to determine the attitude of humans as a social creature who had the spirit of Pancasila and was responsible for the establishment of materially and spiritually fair and prosperous Indonesians.

Revolutionary doctrine caused history education to become 'proclamationcentric' and refereed to Indonesia's socialist society. By the implementation of MANIPOL USDEK, the curriculum had to change because it had to include thoughts in MANIPOL USDEK. It was firmly stated in the instruction of the Ministry of Primary Education and Culture No. 2 the year 1961. As a result of this, education in Indonesia recognized a new subject called Civic to create the modern Indonesians, human-based on MANIPOL USDEK's teaching. This subject then became an obligatory subject in every education level in Indonesia. According to B. 
Wignjoamidjojo in the book entitled MANIPOL Serve Education, this policy showed that politics could not separate the curriculum (Wignjoamidjojo, 1963, p. 35).

In addition to Political Manifesto USDEK concept, politics and education in Indonesia campaigned Marhaenism ideology. This ideology belonged to the group of National Party by Soekarno. Moreover, it once had a massive mass. Still, then Marhaenism was not able to survive even though approximately in 1966 , the ideology was assumed as a revolutionary path, as said by Drs. Gatot Suwiryo in Suluh Marhaenis newspaper on 3 October 1966. Politics also influenced education through government policy. The government policy in education was close to political interest. Education policy came from either the central government or higher education (university) (Suluh Marhaenis, 30 November 1966).

\section{CONCLUSION}

The history curriculum could not be discussed in only one period. It should be chronologically explained because it was interrelated between periods. During 1945 -1951, history education at High School still used the AMS (Algemene Middelbare School) curriculum, which was a legacy from the Dutch Indies era, while the government policy related to the history curriculum during the Sukarno Era, the New Order referred to the policy of political history. It clearly could be seen from the material orientation, which more related to political doctrine, ideology and discussed the role and the greatness of national figures, which led to a single justification towards the struggles. Besides, the policy of history curriculum at high school during the Sukarno Era should be based on the Pancasila and Political Manifesto Usdek (Political Manifesto of UUD 1945 consisted of socialism of Indonesia, Guided Democracy, Guided Economy, and Indonesian Personality). In history curriculum during the early independence precisely after the enactment of Education Laws in 1950, history materials shown at schools displayed colonialists while na- tional figures were still as a compliment. The 1955 curriculum was based on nationalism and internationalism spirits supported by cooperation and kinship. History curriculum design was intended to prevent neoliberalism and anti-capitalism. When Moh Yamin was as Minister of education, the government paid particular attention to history learning. History was assumed as one of the media in building nationalism, whereas history at high school had not mainly taught yet as a history subject like the present day. The ministry of PPK then established the national history committee, which was considered as the only way to prevent divisions and political disintegration as a result of the heated politics before the democratic party. The establishment of the committee was motivated by the government's view of Indonesia's history subject as the strategic media in building the character and personality of the citizens through history teaching. The contradiction debate concerning history learning materials in one side had not been finished yet, and another side politics in Indonesia was increasingly unstable, so encouraged President Sukarno issued Presidential Decree on 5 July 1959. During this time, the concept by Ki Khadjar, which was initially used to instill nationalism to the young generation through history learning, changed into a tool used by the government for the indoctrination process. This process included revolutionary and socialist doctrine, which caused history education to become 'proclamationcentric' and refereed to Indonesia's socialist society. By the implementation of Political Manifesto USDEK, the curriculum had to change because it had to include thoughts in Political Manifesto USDEK.

\section{REFERENCES}

Adam, A. W. (2005). History, nationalism, and power. Social science and power in Indonesia, 247-273.

Aman. (2015). Sejarah Indonesia masa kemerdekaan 1945-1998. Ombak.

Batubara, U. N. (2019). Perkembangan pembelajaran sejarah pasca kemerdekaanreformasi. Jurnal Pendidikan Sejarah, 8(1), 14-34. 
Belen, S. (2010). Sejarah Kurikulum di Indonesia. Pusat Kurikulum Badan Penelitian dan Pengembangan Kementerian Pendidikan Nasional.

Dokumen Indonesia, No. 2, Oktober 1966

Easton, D. (1953). The political system: An inquiry into the state of political science. 1953. Alfred A. Knopf.

Elmore, R., \& Sykes, G. (1992). Curriculum policy. Handbook of research on curriculum, 185-215.

Fadli, MR \& Kumalasari, D. (2019). Sistem Pendidikan Indonesia Pada Masa Orde Lama (Periode 1945-1966). Agastya: Jurnal Sejarah Dan Pembelajarannya, 9 (2), DOI 10.25273/ajsp.v9i2.4168.

Hakim, A., \& Giovani, G. (2012). Perbandingan perekonomian dari masa Soekarno Hingga Susilo Bambang Yudhoyono (1945-2009). Journal of Innovation in Business and Economics, 3(2).

Hakim, L. (2018). Historiografi modern Indonesia: dari sejarah lama menuju sejarah baru. Khazanah.

Hamalik, O. (2004). Proses belajar mengajar. Bumi Aksara.

Hartono, Y. (2017). Model pembelajaran nilainilai karakter bangsa di Indonesia dari masa ke masa. Agastya: Jurnal Sejarah dan Pembelajarannya, 7(01).

Hasan, S. H. (2010). Pengembangan pendidikan budaya dan karakter bangsa. Kemenas Badan Penelitian dan Pengembangan Pusat Kurikulum.

Instruksi Menteri Pendidikan Dasar dan Kebudayaan No. 2 tahun 1961 (Instruction of the Ministry of Primary Education and Culture No. 2 the year 1961)

Kartodirdjo, S. (2000). Pembangunan bangsa dalam perspektif sejara. Historika, 1(1).

Keputusan Presiden No.145 tahun 1965

(Presidential Decree No 145, year 165)

Kochar, S. K. (2008). Pembelajaran sejarah: teaching of history. Grasindo.

Kuntowijoyo. (2013). Pengantar ilmu sejarah.
Tiara Kencana.

Miles, M. H., \& Huberman, A. M. (1994). Qualitative data analysis: an expanded sourcebook. Thousand Oaks CA Sage.

Pewarta PPK No. 2 tahun 1951

Pusponegoro, M. D., \& Notosusanto, N. (Eds.) (2008). Sejarah nasional Indonesia I (edisi pemutakhiran). Balai Pustaka.

Ricklefs, M. C. (2008). A history of modern Indonesia since c. 1200. Macmillan International Higher Education.

Soedjatmoko, D., Resink, G. J., \& Kahin, G. M. (eds.) (1995). Historiografi Indonesia: Sebuah pengantar. PT. Gramedia Pustaka Utama.

Suluh Marhaenis, 30 November 1966

Syukur, A. (2013). Pengajaran Sejarah Indonesia Kurikulum 1964-2004 Sebuah Stabilitas yang Dinamis. PhD. Thesis Fakultas Ilmu Budaya, Program Studi Ilmu Sejarah UI.

Taylor, S., Henry, M., Lingard, B., \& Rizvi, F. (1997). Educational policy and the politics of change. Psychology Press.

Tilaar, H. A. R. (1995). 50 tahun pembangunan pendidikan nasional, 1945-1995: suatu analisis kebijakan. Gramedia Widiasarana Indonesia.

Umasih, U. (2014). Ketika Kebijakan Orde Lama Memasuki Domain Pendidikan: Penyiapan dan Kinerja Guru Sekolah Dasar Di Indonesia. Paramita: Historical Studies Journal, 24(1).

Undang-Undang No. 4 Tahun 1950 (Act of Republic Indonesia number 4, the year 1950 about Fundament of Teaching at Schools)

Undang-Undang No. 12 Tahun 1954 (Act of Republic Indonesia number 12, the year 1954 about the enactment of Act of Republic Indonesia number 4, the year 1950)

Widja, I. G. (1989). Dasar-dasar pengembangan strategi serta metode pengajaran sejarah. Departemen Pendidikan dan Kebudayaan Republik Indonesia.

Zamroni, P. U. D. (2001). Tantangan menuju civil society. BIGRAF Publishing. 